\title{
The Absence of Class Politics in Northern Ireland
}

Article in Capital \& Class · October 1999

DOI: $10.1177 / 030981689906900106$

CITATIONS

12

1 author:

\section{Colin Coulter}

National University of Ireland, Maynooth

38 PUBLICATIONS 213 CITATIONS

SEE PROFILE
READS

156

Some of the authors of this publication are also working on these related projects:

Project stigmatic shaming View project

Project Austerity View project 
These are scarcely auspicious times for the left. An unfortunate confluence of recent social and political trends has conspired to question seriously the value of materialist interpretations of the world. The reconstruction of western societies out of the debris of the economic crises of the nineteen seventies has led to the emergence of increasingly intricate class hierarchies. Changed work practices and accelerated consumption have both served to blur the boundaries between previously distinct social strata. The increasingly complex and dynamic nature of contemporary bourgeois society has invited predictable and indeed opportunistic responses from neoliberal critics. Most famously the political scientist Francis Fukuyama $(1989,1992)$ has declared that we are living through the end of history. The unprecedented material wealth and optimal political freedom that global capitalism has allegedly afforded humanity have ensured, Fukuyama insists, that the notion of social class has effectively ceased to have real meaning.

\section{The Absence of Class Politics in Northern Ireland}

\section{by Colin Coulter}

\section{Introduction}

Those commentators who consider the social significance of class to have declined substantially often make reference to the realm of personal and political identity. The eminent sociologists Anthony Giddens and Ulrich Beck have argued that people living in contemporary society have increasingly come to transcend the influence of social aggregates such as classes. Social actors have apparently begun to dispense with traditional collective identities in order to assemble their own distinctive personal biographies out of the plentiful resources of everyday life. For both Giddens $(1994 ; 1998)$ and Beck $(1992 ; 1994)$ the fluid social relations that have arisen out of the process of globalisation offer the conditions that promise to liberate the individual. The principal authors of the brave new world of flexible accumulation are no longer social classes but rather autonomous individuals. 
The tendency among social scientists to question the salience of the role that class plays within contemporary society is reflected in one of the most important recent analyses of the 'Northern Ireland problem'. In Explaining Northern Ireland John McGarry and Brendan O'Leary offer an impressive exploration of a range of competing interpretations of the troubles. The authors are strongly critical of those readings that have a materialist inflection. Interpretations of the troubles that centre upon the concept of social class, McGarry and O'Leary (1995: 152-61) assert, add little to our understanding of the nature of the conflict within Northern Ireland. People living in the province are considered to be animated principally by those cultural identities and anxieties that are associated with specific ethnonational communities. Preoccupation with the material concerns of social classes, therefore, merely distracts attention from the 'real' source of division within the six counties.

The approach that McGarry and O'Leary adopt makes a great deal of sense of course. Ethnonational sentiment does after all exercise rather greater influence than class consciousness over the outlook and conduct of those who reside within the six counties. Nonetheless the reading of the 'Northern Ireland problem' that the political scientists provide exhibits at least two important shortcomings. Firstly, McGarry and O'Leary would seem to regard the political culture that obtains within the six counties as essentially unidimensional. The interpretation which they advance would appear to rest upon the assumption that only that social identity that exercises greatest influence over the political life of the province 'really' matters. Ethnonational status evidently represents the principal source of political allegiance within Northern Ireland. Those social identities that attend class distinctions are, therefore, afforded merely cursory acknowledgement.

The apparent unwillingness of McGarry and O'Leary to take social class seriously constitutes an important flaw in their work. While socio-economic status clearly represents a less important source of political identity within the six counties than ethnoreligious affiliation it remains crucially significant nonetheless. Social class exercises a palpable-if often unacknowledgedinfluence upon the political culture that exists within the six counties. Their understandable though ultimately debilitating preoccupation with ethnonational distinctions blinds McGarry 
and O'Leary to the significance of the role that class divisions play in the public life of Northern Ireland.

The second criticism that may be levelled at Explaining Northern Ireland is rather more important. In spite of the title which they chose to give to their book, McGarry and O'Leary have a propensity to merely describe that which needs to be explained. At various stages the authors attest that ethnonational affiliation represents the predominant source of political identity and division within Northern Ireland. The reader is never provided, however, with an adequate interpretation as to why precisely this may be so. In the absence of a persuasive explanation we are left with the impression that the prevalence of ethnonational sentiment within Northern Irish political life should be considered inevitable, reasonable, 'natural' even.

The substance of the political culture that exists within the six counties is of course rather more problematic than the silence within McGarry and O'Leary's work would suggest. The predominance of ethnonational sentiment within the public life of the province is far from inevitable. Indeed there are substantial grounds for the argument that social class rather than ethnoreligious affiliation should be the principal author of political belief and practice in Northern Ireland. Socio-economic status certainly has rather greater bearing than ethnoreligious distinction upon the distribution of essential life chances within the six counties. Given the nature of the inequalities within contemporary Northern Irish society one would not have to be a raving reductionist to anticipate that social class might constitute the most important source of political identity in the province. In reality of course this is not the case. The political culture that prevails within Northern Ireland flies in the face of the material realities of existence in the six counties. That ethnonational allegiance manages to exercise most influence over the political life of the province should not, therefore, be accepted on face value but rather should be acknowledged as a problematic that demands proper explanation.

The purpose of this particular essay then is to resist an essentially regressive trend within contemporary social science. The discussion that follows sets out to illustrate that social class has an enormous impact upon the manner in which Northern Irish society is structured and experienced. Socio-economic distinctions are clearly implicated in the ways in which the social actors in the province think, feel and act. An appreciation of 
the crucial role that social class plays in the lives of the residents of the six counties should be considered essential, therefore, to an adequate understanding of the nature of contemporary Northern Irish society.

\section{The Salience of Social Class}

The particular form of contemporary Northern Irish society has arisen out of a specific and complex process of capitalist development that has spanned the past couple of centuries. Northern Ireland clearly exhibits all of the inequities and disparities that are the classic hallmarks of bourgeois society (Wilson, 1989: 13). The existence of substantial class divisions within the six counties becomes readily apparent when we consider the distribution of income within the province. Information garnered by the British Treasury reveals that the different social strata within Northern Ireland experience vastly divergent life chances (Milburn, 1994). In 1994 the collective earnings of the most affluent ten per cent of Northern Irish taxpayers actually exceeded those of the least affluent fifty per cent. The disparities in earnings that have always existed within the six counties have become even more pronounced in recent decades.

The accession to power of Margaret Thatcher in the spring of 1979 heralded an era of growing inequality throughout the entire United Kingdom. When the Conservatives entered office the gap between rich and poor within Northern Ireland was already enormous. During the fiscal year 1980/81 the most wealthy ten per cent of the province's economically active population received incomes that were on average eight times greater than those of the least wealthy fifty per cent. With the passage of time this particular ratio of inequality has grown appreciably. The social and economic policies that were implemented by successive Conservative administrations have ensured that the void between the 'haves' and the 'have nots' within Northern Irish society has widened alarmingly over the last generation. By the tax year 1993/94 the top decile of wage earners in the province had come to enjoy incomes that were on average thirteen times larger than those received by the bottom half.

The information furnished by Her Majesty's Treasury reveals Northern Ireland to be a society characterised by substantial and growing material inequalities. The profoundly inequitable 
nature of the six counties finds further pertinent expression in prevailing patterns of academic attainment. In contrast to some other regions of the United Kingdom, Northern Ireland has retained a distinctly selective system of education. Northern Irish children undertake standard intelligence tests around the age of eleven which determine the mode of secondary level education that they will receive. Success in the eleven plus examinations has an enormous bearing upon future academic progress (Gallagher, 1995). Those youngsters who pass are entitled to a place in one of the province's grammar schools. These prestigious institutions frequently boast impressive scholastic standards and routinely attain the best external examination results in the United Kingdom. Northern Irish grammar schools cater principally for the children of the professional and business classes. Cormack and Osborne (1995: 503) note that seven out of every ten pupils enrolled in the province's grammar school network have parents engaged in non-manual employment.

The majority of children who undertake the educational transfer procedure in Northern Ireland do so unsuccessfully. Those who fail the eleven plus examinations are educated in secondary intermediate schools. These institutions are intended to offer a general education to pupils deemed unsuited to academic pursuits. Most of the children who attend secondary intermediate schools are drawn from working class communities. Cormack and Osborne calculate that two thirds of pupils enrolled in secondary intermediates have parents employed in manual labour. The resources that secondary schools receive are merely a fraction of those lavished upon the province's grammar schools (ibid: 513 ). The relative and absolute underfunding that secondary schools have endured has inevitably been mirrored in patterns of scholastic attainment. While some secondary schools in the province have attained respectable academic standards, many others remain extremely poor. As a result, the proportion of Northern Irish teenagers who leave school without any formal qualifications runs high relative to the United Kingdom average (ibid: 505-506; Gallagher, 1995; Sheehan and Tomlinson, 1995).

The particular system of education that operates within the province, therefore, radically differentiates pupils along socioeconomic lines. Children from middle class backgrounds in the main attend grammar schools that usually offer an excellent 
academic education. Working class pupils, in contrast, typically go to secondary intermediates which frequently have poor academic standards. The process of selection at work within the province's education system clearly offers principal advantage to the children of the professional and business classes. Northern Irish schools are, therefore, instrumental in reproducing the enormous socio-economic disparities that obtain within the six counties.

The distribution of life chances within the six counties evidently and inevitably bears the inscription of social class. Socio-economic status has also exercised an important influence upon the manner in which the lamentable events that have overtaken the province since the late sixties have been experienced. The political violence that has marred recent Northern Irish history has at one stage or another touched the lives of most people who reside within the six counties (Ruane, 1996). The troubles have, however, impacted most gravely upon the province's lower orders (Feldman, 1991). Most of those who have played a direct role in the conflict have been drawn from working class communities. The local security forces have generally recruited from 'respectable' elements of the Protestant working classes (Brewer and Magee, 1991). The agents of unofficial forms of violence have also come overwhelmingly from working class backgrounds. The research carried out by Louise Shara (1994) indicates that almost all of those charged with politically motivated offences are either unemployed or engaged in semi-skilled or unskilled manual labour.

Most of the people who have killed during the modern conflict in Northern Ireland have come from working class backgrounds. So too have most of the people who have lost their lives (Fay et al., 1999: 141-55). The significant absence of appropriately detailed information means that it is difficult to capture precisely the socio-economic characteristics of those who have died during the troubles. We may nevertheless be able to construct a reasonably accurate class profile of the victims of political violence in Northern Ireland through examination of the spatial distribution of fatalities. Adopting this approach bears out anecdotal evidence that the political violence that has overtaken Northern. Ireland since the late sixties has proved particularly lethal for the residents of working class districts.

A decade ago Michael McKeown undertook the unenviable task of analysing the two thousand seven hundred and sixty 
three deaths that had occurred during the opening twenty years of the troubles. The information that McKeown (1989: 50) presents clearly confirms that those regions of the six counties that are materially disadvantaged have also experienced disproportionately high levels of political violence. This coincidence becomes especially evident when we examine the electoral constituencies of North and West Belfast. While neither district could be characterised as universally poor, both contain some of the most extreme concentrations of poverty that exist in Northern Ireland (Gaffikin and Morrissey, 1995: 53). The inhabitants of North and West Belfast have endured rather greater levels of political violence than those of any other part of the province. Over the first two decades of the troubles the death toll in each district was the strangely identical figure of five hundred and forty four fatalities. The contrast with the most affluent region of the six counties could hardly be more dramatic. The residents of North Down have been relatively sheltered from the conflict that has engulfed Northern Ireland over recent generations. Between 1969 and 1989 the number of residents of the province's 'gold coast' who lost their lives to political violence was the remarkably small total of eight.

\section{Class as a Social Identity}

Even the necessarily cursory survey offered above confirms contemporary Northern Irish society to be deeply differentiated along class lines. The enormous inequalities that attend socioeconomic distinctions are clearly revealed in the patterns of academic attainment and income distribution that obtain within the six counties. Class position evidently exerts an important influence over the allocation of life chances in Northern Ireland. The salience of socio-economic status has not been lost upon the citizens of the province. There exists ample evidence that social class has considerable bearing upon the manner in which people in Northern Ireland define both themselves and others.

The data yielded by large scale survey research suggests that socio-economic status impinges strongly upon the consciousness of social actors living in the six counties. People in the province emerge as critically aware of the multiple significance of class background. The consciousness of the Northern Irish working classes would appear especially acute. 
Those annual surveys conducted under the auspices of the British Social Attitudes project have consistently shown that working class people in the province are overwhelmingly aware of the material inequalities that mark the social order under which they live (Hayes and McAllister, 1997). Around three quarters of working class respondents have consistently acknowledged that there exist iniquitous disparities in wealth among the citizens of Northern Ireland (O’Dowd, 1991: 45).

Northern Irish people would seem strongly aware that class origins are deeply implicated in the distribution of life chances within the six counties. It scarcely comes as a surprise, therefore, to learn that socio-economic status is crucial to the definitions of self that social actors in the province construct. Surveys conducted in the six counties have invariably revealed that people are readily familiar with the systems of classification that are associated with class distinctions. Northern Irish respondents are typically willing and able to allocate themselves to specific locations within the hierarchy of class relations. Indeed, people living in the six counties often prove more capable of assigning accurate class identities to themselves than citizens of other countries conventionally assumed to possess more developed systems of socio-economic distinction. The Northern Irish working classes emerge as particularly familiar with the taxonomy of bourgeois society. International data collated by Hayes and McAllister (1995: 356) reveals that working class residents of the six counties are more likely to identify their socio-economic status accurately than workers living in any other western state.

The responses that have been produced by surveys conducted in Northern Ireland are perhaps significant. The apparent familiarity of Northern Irish respondents with the classifications associated with capitalist society suggests that socio-economic status strongly informs the outlook of social actors living in the region. Social class would seem to impinge upon who and what the people of the province consider themselves to be. Socioeconomic status influences not only how Northern Irish people define themselves but also how they regard others. The information that has emerged from the annual British Social Attitudes survey intimates that class generates feelings of solidarity among the residents of the six counties. Two out of every three respondents acknowledged 'feeling close' to others from similar socio-economic origins. The sentiments of kinship that arise out of social class were of 
equal magnitude to those produced by ethnoreligious identity (Moxon-Browne, 1991: 27).

The identities that people in Northern Ireland embrace clearly bear the mark of socio-economic status. Social class strongly influences the manner in which individuals understand both themselves and others. The inhabitants of the six counties possess an intimate knowledge of the specific ethnographic cues that signify socio-economic distinction. While less extensive and exotic than the markers of ethnoreligious persuasion, the signifiers of class status constitute an important resource upon which social actors draw in everyday situations. Accent, style of dress, secondary level school attended, cultural appetites and so on will alert individuals to the socio-economic origins of those with whom they come into contact (Sennett and Cobb, 1972; Steedman, 1986). Awareness of the class background of those one encounters may subtly alter the form of interaction. Socio-economic distinctions frequently give rise to strong feelings of antipathy. Although less virulent than the hostility that often emerges out of ethnoreligious conviction, the prejudice associated with social class can often sour relations and prevent specific forms of personal interaction. The strength of ethnoreligious enmity within the six counties has served little to dilute the snobbery which Northern Ireland shares in common with other capitalist societies.

\section{Class as a Political Identity}

Examination of contemporary Northern Irish society attests to the enormous significance of social class. Socio-economic location evidently serves to determine the resources and opportunities available to individuals. Social actors are keenly aware that class status regulates the distribution of life chances within the six counties. The class consciousness that informs the outlook of people living in Northern Ireland would seem, however, to have had little effect upon the political culture of the province. The ideological formations that are prevalent within the six counties would appear to arise not out of class sentiment but rather out of ethnic or national feeling. It is, of course, ethnonational status that fundamentally determines who social actors in the province are willing to vote for, willing to talk to and -in extreme circumstances-willing to kill. 
While ethnonational affiliation may well represent the principal author of political identity in Northern Ireland it is, however, by no means the only one. Ethnic or national sentiment evidently define the parameters and contours of political life in the province. Within the ideological framework that ethnonational conviction has constructed, however, other forms of social identity, and most notably those that emerge out of socioeconomic position, exercise a palpable influence (Hayes and McAllister, 1997; McAuley, 1994: 2, 52, 124-9, 181; O’Dowd, 1990: 63). Social scientists and other commentators have often been content to ignore the crucial role that social class plays in the political culture of the province. The manner in which ethnonational feeling and class sentiment interact to produce political identity in the six counties is equally apparent in the case of both Irish nationalism and Ulster unionism. For reasons of brevity the discussion that follows will address solely the former ideological formation.

\section{Irish Nationalism}

Those diverse individuals who belong to the nationalist tradition within Northern Ireland share a profound sense of community (Todd, 1990). The ideological and emotional bonds that exist between nationalists living in the six counties are revealed and strengthened during periods of political turmoil. The fateful hunger strikes initiated in the early eighties managed to generate sympathy even among Northern Irish Catholics sternly opposed to the republican movement. The tense standoffs that have developed at Drumcree over the last few summers offer more recent evidence that nationalists of all backgrounds can at times find common political cause (Douds, 1996).

Even after the tumultuous events of the past three decades nationalists living in the six counties still share many political interests and grievances. The era of the troubles has nonetheless recorded a substantial widening of traditional divisions among nationalist ranks (Ruane and Todd, 1992: 202-9). The ideological fissures that have grown within Northern Irish nationalism have acknowledged the changing class composition of the Catholic community in the province. The introduction of 'direct rule' in the spring of 1972 initiated a sequence of processes that has amplified existing socio-economic divisions among northern 
nationalists. A large section of the nationalist community has derived enormous benefit from the policies that have been implemented by various Westminster administrations (Shirlow and McGovern, 1997: 193, 197). The expansion of places in third level education - coupled with the growing tendency of middle class Protestants to opt for universities in Great Britain - has enhanced the academic opportunities available to nationalist youths. The creation of thousands of jobs in the public sector has meant that many of the more able and ambitious members of the current generation of nationalists have been able, unlike their predecessors, to translate formidable academic attainment into lucrative and secure employment (O'Connor, 1993: 14). Some nationalists who have been recruited into state institutions have of course encountered obstacles that have impeded their career development. The advances that members of the nationalist community have secured through public employment remain significant nonetheless.

The era of direct rule has offered many within the nationalist community unprecedented opportunities for social mobility. As certain Northern Irish Catholics have ascended the class hierarchy a distance has opened up between themselves and their fellow nationalists that is both social and spatial. Over time burgeoning affluence has enabled many upwardly mobile nationalists to move away from districts populated exclusively by their ethnopolitical kin. These changing patterns of residence have assumed an especially significant form within the regional capital. The district of south Belfast that centres upon the Malone Road was historically the preserve of wealthy unionists. The few Catholics who lived in the neighbourhood were usually servants working in the sumptuous residences that characterise the area (Sharrock, 1995). In recent times, however, the ethnoreligious composition of Belfast's most exclusive district has undergone remarkable change. Members of the new Catholic middle classes have begun to acquire addresses along the Malone Road and its numerous leafy arteries (Smyth, 1991: 144). Indeed there has been some speculation that nationalists now outnumber unionists among the residents of Belfast's most prestigious neighbourhood (Brennock, 1991).

The shifting ethnoreligious credentials of those who live in the leafy avenues of south Belfast provides an important illustration of the gains that many Northern Irish nationalists have made over the last couple of decades. The benefits that 
direct rule has bestowed upon the nationalist community have, however, been far from universal. The policies that Westminster has implemented have enhanced the opportunities for wealth and social mobility of some northern nationalists. Others within the nationalist fold have proved rather less fortunate.

The series of economic and political crises that have befallen Northern Ireland over recent generations have impacted with especial severity upon sections of the nationalist working classes. Unemployment represents a particular problem for working class Catholics and, more specifically, for working class Catholic men. The decline of the construction industry has eroded further the employment opportunities available to working class nationalists who have invariably proved either unwilling or unable to seek work within the greatly expanded security sector. As a consequence, working class Catholic men tend to be heavily over-represented among the ranks of the province's unemployed. Indeed nationalist males are presently more than twice as likely as their unionist counterparts to be out of work. This particular index of the inequalities that exist between the principal ethnoreligious communities in Northern Ireland has altered little since the early nineteen seventies (Aunger, 1975; O’Dowd, 1995: 154-5).

The greater likelihood that nationalists will find themselves out of work is captured in the spatial distribution of unemployment within the six counties. Those parts of Northern Ireland that exhibit exceptionally high levels of joblessness are invariably populated primarily by nationalists (Sheehan and Tomlinson, 1995). The alarming unemployment rates that exist in districts such as west Belfast, Strabane, the city side of Derry and so forth ensure that the Catholic working classes are particularly likely to experience low income, poverty and reliance upon state agencies. The disadvantage and dependence that characterise the position of many working class nationalists become apparent when we consider the distribution of a specific welfare benefit within the six counties. School dinners are supplied free to children whose parents are unemployed and receiving income support from the state. A report published in the mid nineties reveals that the recipients of this particular welfare provision tend to be concentrated heavily in Catholic schools (McGill, 1995). The document in question notes that some thirty five per cent of Catholic pupils are entitled to receive free dinners compared to only fifteen per cent of their Protestant counterparts. 
The violence of the last three decades has been especially traumatic for the nationalist working classes. The enormous resources of the British military have been deployed in the main to regulate and repress working class nationalist communities. The coercive conduct of the security forces has ranged from the routinised attrition of multiple forms of surveillance to the murder of unarmed political demonstrators. Hence, while the British state may frequently relate the nationalist middle classes as a generous benefactor it often relates to working class nationalists as a tireless oppressor. Working class Catholics have also been the principal victims of that violence that has originated within the loyalist community. Remarkably few of the nationalists who have been murdered by loyalist paramilitaries in the course of the troubles have belonged to the republican movement. Between 1969 and 1993 loyalists murdered sixty four people who could be considered republican activists. During the same period six hundred and seventy nationalists who had no formal association with the republican movement lost their lives at the hands of loyalist paramilitaries (McGarry and O'Leary, 1995: 160). Most of the nationalists who have died as a result of unofficial violence have been drawn from working class neighbourhoods. The composition of nationalist fatalities during the troubles reveals that the principal victims of loyalist paramilitarism have been randomly selected members of the Catholic working classes. The indiscriminate nature of loyalist violence has meant that every resident of certain working class nationalist districts is -in principle at least-at risk. Consequently the strategy that loyalist paramilitary factions have adopted has tended to spread fear throughout entire working class Catholic communities.

The interests and experiences of the class fragments that comprise the 'nationalist community' have, therefore, diverged considerably since the introduction of direct rule. The process of class polarisation at work among Northern Irish nationalists has inevitably produced and reproduced ideological divisions which have come to be indexed, albeit crudely, in patterns of electoral allegiance (Ruane and Todd, 1992: 206-7; 1996: 71-4, 166-70). The socio-economic profiles of those who support the two largest nationalist political parties within the six counties are rather different (Irvin and Moxon-Browne, 1989; Ryan, 1994: 66). While the Social Democrat and Labour Party (SDLP) attracts votes from many working class nationalists, 
the electoral strength of the party stems primarily from its enduring appeal among the Catholic middle classes (Evans and Duffy, 1997: 58-9). The approach that the SDLP has advocated has been that of edging towards a united Ireland through a gradual and inclusive process of political and cultural dialogue. The political strategy endorsed by the party would seem to have chimed with the interests and ambitions of middle class nationalists (Mitchell, 1991: 346; O'Connor, 1993: 35, 43, 49, $52-3$ ). The promotion of the ideal of a united Ireland clearly accords with the deep sense of Irishness that persists among upwardly mobile Catholics living in the six counties. At the same time, the pursuit of that particular ideal through a political strategy that is distinctly gradualist serves to accommodate the instrumental concerns of those nationalists who are fearful that radical change will erode the substantial material gains that have been secured under the auspices of direct rule.

The electoral constituency which Sinn Féin draws upon differs somewhat. Since its re-emergence in the early nineteen eighties Sinn Féin has operated primarily as the voice of the more marginalised elements among the nationalist working classes (Evans and Duffy, 1997: 72; Irvin and Moxon-Browne, 1989) The political wing of the republican movement has conventionally advocated terminating the Union through force of arms. This radical strategy would seem to have appealed to many of those working class Catholics who have enjoyed few of the economic advantages that have flowed from direct rule and who have had to bear the brunt of the habitual repression meted out by agents of the state.

During the present decade the radicalism of Sinn Féin has waned demonstrably. The political goal of the republican movement remains of course the establishment of a unitary Irish state. In recent years, however, many republicans have come to the realisation that the creation of a united Ireland will occur neither in the immediate future nor indeed through force of arms (Shirlow and McGovern, 1998). The growing circumspection of Sinn Féin would also appear to have altered the outlook of the party on social and economic matters. Through an extensive network of grassroots organisations republicans continue to seek to represent and advance the interests of the nationalist working classes. The references to socialism that once informed the discourse of Sinn Féin have, however, all but disappeared. 
The process of revision that Sinn Féin has undergone in recent years would seem to have broadened considerably the appeal of the party. The numerous elections that have punctuated the evolution of the 'peace process' have witnessed increases in the republican vote that few observers would have anticipated. The electoral advances that Sinn Féin has secured lately may perhaps reflect the growing attraction that the party exercises among middle class nationalists. Having apparently embraced at least the essence of the prevailing neoliberal orthodoxy on economic affairs contemporary republicanism could hardly be considered a threat to the appreciable material interests of the new nationalist middle classes. The movement of Sinn Féin towards a strategy of 'unarmed struggle', moreover, has probably appealed to those upwardly mobile Catholics who consider the SDLP to be insufficiently resolute but who have been unwilling to shoulder the moral responsibility associated with political violence. The growing popularity of Sinn Féin among the nationalist middle classes was illustrated in a particular triumph during the 1997 local government elections. In north Belfast the party polled well as anticipated in the traditional fastness of the working class New Lodge district. Rather less expected were the many votes that Sinn Féin received from middle class nationalists living in the tree-lined avenues that side the lower stretches of the Antrim Road. The electoral advances that Sinn Féin made in north Belfast were crowned when the party captured a seat in the affluent Castle ward.

\section{Why Ethnonational Rather Than Class Politics?}

The political culture that obtains within Northern Ireland accommodates a range of social interests and identities. In particular the public life of the province acknowledges the complex interplay of those political personae that arise out of socio-economic status and ethnonational distinction respectively. The crucial interchange that conjoins class sentiment on the one hand and ethnic or national feeling on the other does not, however, represent a relationship between equals. On the contrary in fact. Within the incessant dialogue that takes place between class consciousness and ethnonational orientation it is the latter that invariably speaks with the louder voice and that almost always has the last word. ${ }^{1}$ 
The predominance of ethnic and national affiliation as sources of political identity within Northern Ireland is in some respects perplexing. Ethnonational status certainly has an enormous impact upon the experiences and opportunities of social actors living in the six counties (O'Dowd et al., 1980). It is entirely fitting, therefore, that the political life of the province should bear the indelible impression of ethnic and national sentiment. While ethnonational affiliation profoundly affects the lives of people in Northern Ireland, its significance remains nonetheless subordinate to that of social class. Socio-economic status exercises rather greater influence than ethnic or national identity over the distribution of life chances within the six counties. Whether people are working class or middle class is simply more important than whether they are Protestants or Catholics when it comes to whether they will secure employment, the nature of the job they will get, the standard of education they will receive, the type of schools their children will attend, how long they will live (Kilbane, 1995), whether or not they will be killed or injured as a result of politically motivated violence and so on.

Examination of the massive inequalities that blight contemporary Northern Irish society suggests that social class possesses rather greater material significance than ethnicity or nationality. In most respects the Protestant and Catholic working classes have substantially more in common with one another than with their more privileged ethnonational kin. Moreover, the survey data presented earlier would indicate that working class people living in the province who come from different ethnoreligious backgrounds often have a strong appreciation of their mutual material interests. The class consciousness that would seem prevalent within Northern Ireland has, however, had only limited impact upon the political life of the province. Socio-economic status represents a strictly secondary source of political identity within the six counties. While the political alliances forged within the province routinely transcend class barriers only rarely do they supersede ethnoreligious distinctions. The inability of social class to displace ethnonational affiliation as the principal author of political belief and practice within Northern Ireland may be explained in at least two ways.

Firstly, the pre-eminence of ethnoreligious sentiment within the political culture of the province may be attributed to the 
machinations of certain influential players within the six counties. Those resilient ethnic divisions that characterise the region have often served handsomely the particular interests of the more elevated strata within Northern Irish society. Preoccupation with the 'imagined communities' of the ethnie or nation has typically ensured that the working classes within the six counties have failed to act upon their critical understanding of the interests and grievances that they share. The prevalence of ethnic sentiment within the province has, therefore, served to dissipate the forces of social radicalism. Those who have derived greatest benefit from the bourgeois social formation that exists within Northern Ireland have inevitably - and with some success sought to encourage ethnoreligious feeling. The more privileged elements of the unionist community have proved particularly adept at fomenting ethnic division among the working classes.

For most of this century Ulster unionism was under the control of capitalists and large landowners. Those powerful interests that dominated unionist politics until the outbreak of the present troubles were evidently concerned to retain the allegiance of the Protestant working classes. Prominent unionist politicians routinely employed a populist discourse that centred upon Protestant supremacism. Furthermore, the leadership of the Ulster Unionist Party (UUP) was anxious to be seen to be taking on board the interests and grievances of working class loyalists. As the First World War came to a close many Protestant workers became heavily involved in a spate of important industrial disputes. Those wealthy men at the helm of Ulster unionism quickly moved to stem the seemingly rising tide of proletarian radicalism. In 1918 the Ulster Unionist Labour Association (UULA) was formed (Collins, 1994: 145-6). Over the next half century the UULA provided a channel through which representatives of the unionist working classes were assigned to the lesser positions within Stormont administrations (Bew et al, 1979: 48-9). The association would appear to have performed with considerable success the role for which it was designed. During the period of devolved government at Stormont there were a few occasions when the unionist working classes sought to pursue those substantial interests held in common with Catholic workers. In the main, however, working class Protestants proved content to exist as subordinates within the unionist class alliance. When the unionist working classes eventually did turn resolutely against 
the Stormont regime they did so for reasons that owed more to ethnoreligious prejudice than proletarian solidarity.

The concern of the leaders of unionism to maintain the support of working class Protestants has found a further, more contemporary, illustration. In 1995 various individuals who were broadly sympathetic to the British Labour Party and who belonged mainly to the UUP came together to form a political pressure group. The formal purpose behind the establishment of this Labour grouping was to provide a voice to those who did not share the conventional conservatism of mainstream unionism with regard to social and economic matters. The creation of the pressure group may also be interpreted as an attempt to fend off growing competition for the electoral allegiance of the unionist working classes. In recent years the smaller loyalist parties - and in particular the Progressive Unionist Party (PUP) - have begun to highlight and promote the particular and abundant concerns of working class Protestants (Finlayson, 1999: 90; McAuley, 1997: 165-9). The formation of a Labour grouping broadly within the orbit of the UUP constitutes a measure designed to prevent support haemorrhaging to the 'fringe' loyalists. The existence of the coalition suggests that the interests of the Protestant lower orders are being advanced within the unionist mainstream. In reality, however, the creation of a Labour chapter represents merely another empty cynical gesture on the part of a political party that has consistently abused and ignored the unionist working classes.

Examination of pertinent developments within unionism over the course of the twentieth century reveals the ability of a social and political elite within the six counties to regulate and reproduce ethnonational division. Those privileged men who have traditionally run unionism have consistently sought to encourage the Protestant lower orders to believe that their true interests lie with their ethnoreligious kin rather than their nationalist fellow workers. Their efforts have clearly borne fruit. The enmities that fester among the province's working classes offer lucid testimony to the machiavellian skill of the most elevated strata within Northern Irish society.

Secondly, the substance of the political culture that prevails within Northern Ireland may be attributed to the particular discursive forms that arise out of ethnic feeling and class sentiment respectively. Those ideological formations that emerge from ethnic and national identities often have a merely tenuous 
relationship with historical and contemporary realities. Intellectuals, artists and others who strive to promote the interests of ethnonational communities are at times economical with the truth. Those stories that testify to the glory of the nation or ethnie frequently have little or no basis in fact. That the dominant narratives of the ethnonational tradition may be erroneous does not of course diminish their appeal. Social actors have consistently proved willing and able to cling to tales and beliefs long since debunked by the academy. The emotional power that defines ethnic and national identities derives largely from the rich figurative systems that they produce. The existence and value of the ethnonational community are vividly articulated through anthems, flags and emblems that stir the blood of those within and without the laager.

The distinctive symbolic systems that actualise the nation and ethnie are routinely able to reduce people to tears or move them to violence. Socio-economic status rarely seems capable of generating a comparable emotional charge. In part this is because of the particular form of political discourse that arises out of social class. Those social actors who seek to advance specific class interests - or at least those of the lower orderstend to possess a relatively faithful disposition to the 'truth'. Representatives of the working classes will typically be concerned to outline the 'simple facts' concerning the inequities and divisions that are the hallmark of capitalist society. Statistics that illustrate unemployment, low income and poor housing will often produce feelings of outrage. The narratives of working class existence that these data advance simply cannot, however, match the frequently altogether more fantastic tales that delineate the supposed experience of the nation or ethnie.

Socio-economic status rarely enjoys an affective power comparable to that of ethnicity or nationalism largely because it fails to produce an equally potent symbolic programme. All social classes as a matter of course construct distinctive systems of cultural representation and distinction. Working class communities constantly produce and reproduce a collection of stories, songs and images that recount their specific experience. The cultural texts that are generated by social classes tend, however, to exercise a lesser appeal than those that originate within the nation or ethnie. It is 'the Sash' or 'the Soldiers' Song' rather than 'the Internationale' that brings tears to the eyes of working class men as the end of licensing hours beckons. 
The nation and ethnie have, therefore, come to represent the principal authors of political allegiance within the six counties due largely to their ability to produce particularly persuasive discursive forms. Ethnonational distinctions provide the essence of the province's political culture not because they are the most important source of inequality in Northern Ireland. Socioeconomic status has an altogether more substantial bearing upon the iniquitous distribution of life chances within the six counties. Ethnonational communities have managed to lay stronger claims than social classes to the political loyalties of people living in Northern Ireland not because they have greater material significance but rather because they tell better stories.

\section{Conclusion}

As we face into a new century there are many people living in Northern Ireland who harbour a sense of optimism that would have been inconceivable only a few years ago. The political compromise thrashed out at Stormont in the spring of 1998 would seem to mark a dramatic turn in the fortunes of the province. In certain regards the Good Friday Agreement would appear to hold out the prospect of real political progress within the six counties (O'Leary, 1999). The implementation of the Accord would mean an end to the brutal campaigns of violence sustained by loyalist and republican paramilitaries alike over the last three decades. Working class men would cease to kill and maim other working class men in the name of competing though equally worthless nationalisms. That would of course be a turn of events genuinely worth celebrating.

The orchestrated euphoria that has attended recent political developments in Northern Ireland should not, however, be allowed to cloud our critical judgement. Almost inevitably, the Belfast Agreement exhibits traits that are thoroughly objectionable, not least to socialists. The tone of the document frequently seems to exude a sense of pluralism. In reality though the Good Friday Agreement rests upon an understanding of the nature of contemporary Northern Irish society that turns out to be oppressively narrow. Within the text the residents of the province are constructed purely as representatives of one or other of the ethnonational traditions prevalent within the six counties. Under the terms of the Good Friday Agreement the 
people of Northern Ireland are entitled solely to be unionists or nationalists. The prospect that social actors in the province might prefer to construct themselves in terms of gender, sexuality, age or more individuated inclinations is blithely ignored. The most important distinctions that exist in Northern Ireland or any other bourgeois society-namely those that pertain to class-are simply written out of existence.

The architects of the Belfast Agreement evidently presume that those ethnonational programmes that have plagued Northern Ireland over recent generations will continue to consume the political life of the province for the foreseeable future. These presumptions will almost inevitably come to assume the status of a self-fulfilling prophecy. The impulses that inform the Good Friday Agreement seek not to bury unionism and nationalism but rather to praise them. The deal brokered at Stormont signals that substantial material and figurative resources will be employed in order to confer legitimacy upon morally bankrupt political ideologies that have nothing to offer the people of Ireland, north or south, other than yet more misery. The ethnonational reaction that gnaws at its heart reveals the Belfast Agreement as an enterprise that has neither the ability nor indeed the intention of creating a just and progressive society on the island. The need for class politics remains as pressing as ever.

1. The sovereignty that ethnonational feeling frequently exercises over class sentiment was perhaps illustrated with greatest clarity during one of the most important early passages of the troubles. In the spring of 1974 the ramshackle Ulster Workers' Council (UWC) organised an industrial stoppage that would eventually prove enormously effective (Anderson, 1994; Nelson, 1984: 155-60). The success of the strike revealed the considerable influence at the disposal of sections of the Northern Irish working classes. This power was, however, used not to advance the interests of workers but rather to prosecute regressive ethnonational concerns. The reactionary events of May 1974 merely confirm that the most squalid versions of ethnonationalism are at times able to appropriate the language and form of class politics.

Anderson, D. (1994) 14 May Days: The Inside Story of the Loyalist Strike of 1974. Gill \& Macmillan, Dublin.

Aunger, E.A. (1975) 'Religion and Occupational Class in Northern Ireland, in Economic and Social Review 7 (1): 1-18.

Beck, U. (1992) Risk Society: Towards a New Modernity. Sage, London.

(1994) 'The Reinvention of Politics: Towards a Theory of Reflexive Modernisation', in U. Beck, A. Giddens and S. Lash (eds.) Reflexive 
Modernisation: Politics, Tradition and Aesthetics in the Modern Social Order. Polity, Cambridge: 1-55.

Bew, P., P. Gibbon and H. Patterson (1979) The State in Northern Ireland 1921-72: Political Forces and Social Classes. Manchester University Press, Manchester.

Brennock, M. (1991) 'Guess Who's Coming to Belfast 9?', in Irish Times, 23 March. Brewer, J. and K. Magee (1991) Inside the RUC. Clarendon, Oxford.

Collins, P. (1994) 'Irish Labour and Politics in the Late Nineteenth and Early Twentieth Centuries', in P. Collins (ed.) Nationalism and Unionism: Conflict in Ireland, 1885-1921. Institute of Irish Studies, Belfast: 123-54.

Cormack, R. and R. Osborne (1995) 'Education in Northern Ireland: The Struggle for Equality' in P. Clancy et al (eds.) Irish Society: Sociological Perspectives. Institute of Public Administration, Dublin.

Douds, S. (1996) 'All Croppies Together', in Fortnight 353.

Evans, G. and M. Duffy (1997) 'Beyond the Sectarian Divide: The Social Bases and Political Consequences of Nationalist and Unionist Party Competition in Northern Ireland', in British Journal of Political Science 27: 47-81.

Fay, M., M. Morrissey and M. Smyth (1999) Northern Ireland's Troubles: The Human Costs. Pluto, London.

Feldman, A. (1991) Formations of Violence: The Narrative of the Body and Political Terror in Northern Ireland. University of Chicago Press, London.

Finlayson, A. (1997) 'Discourse and Contemporary Loyalist Identity', in P. Shirlow and M. McGovern (eds.) Who Are 'the People'? Unionism, Protestantism and Loyalism in Northern Ireland. Pluto, London: 72-94.

Fukuyama, F. (1989) 'The End of History', in The National Interest, Summer. Hamish Hamilton, London: 3-18.

(1992) The End of History and the Last Man.

Gaffikin, F., and M. Morrissey (1995) 'Taxation: The Cost of Inclusion', in Democratic Dialogue (eds.) Social Exclusion, Social Inclusion. Report No.2, Belfast: $53-5$.

Gallagher, T. (1995) New Schools For New Times', in Democratic Dialogue (eds.) Social Exclusion, Social Inclusion. Report No.2, Belfast: 62-4.

Giddens, A. (1994) 'Living in a Post-Traditional Society', in U. Beck, A. Giddens and S. Lash (eds.) Reflexive Modernisation: Politics, Tradition and Aesthetics in the Modern Social Order. Polity, Cambridge: 56-107.

(1998) The Third Way: The Renewal of Social Democracy. Polity, Cambridge.

Hayes, B. and I. McAllister (1995) 'Social Class, Class Awareness and Political Beliefs in Northern Ireland and the Republic of Ireland', in Economic and Social Review, 26:4.

(1997) 'Economic Beliefs and Politics in Northern Ireland', in R. Breen, P. Devine and L. Dowds (eds.) Social Attitudes in Northern Ireland: The Sixth Report. Blackstaff, Belfast.

Irvin, C. and E. Moxon-Browne (1989) 'Not Too Many Floating Voters Here', in Fortnight 273.

Kilbane, P. (1995) 'Partners in Health?', in Democratic Dialogue (eds) Social Exclusion, Social Inclusion. Report No.2, Belfast: 65-7. 
McAuley, J.W. (1994) The Politics of Identity: A Loyalist Community in Belfast. Avebury, Aldershot.

(1997) "Flying the One-Winged Bird": Ulster Unionism and the Peace Process', in P. Shirlow and M. McGovern (eds.) Who Are 'the People'? Unionism, Protestantism and Loyalism in Northern Ireland. Pluto, London: 158-75.

McGarry, J. and B. O'Leary (1995) Explaining Northern Ireland: Broken Images. Blackwell, London.

McGill, P. (1995) 'Far More Catholic Children in North Live in Poverty', in The Irish Times, 28 December.

McKeown, K. (1989) Two Seven Six Three. Murlough, Lucan.

Milburn, A. (1994) 'Class Act', in Fortnight 328.

Mitchell, E. (1991) Class and Ethnicity in the Perpetuation of Conflict in Northern Ireland, unpublished $\mathrm{PhD}$ dissertation. New Jersey, Rutgers.

Moxon-Browne, E. (1991) 'National Identity in Northern Ireland' in P. Stringer and G. Robinson (eds.) Social Attitudes in Northern Ireland: 1990-91. Blackstaff, Belfast.

Nelson, S. (1984) Ulster's Uncertain Defenders: Loyalists and the Northern Ireland Conflict. Appletree, Belfast.

0'Connor, F. (1993) In Search of a State: Catholics in Northern Ireland. Blackstaff, Belfast.

O'Dowd, L. (1990) 'New Introduction', in A. Memmi, The Coloniser and the Colonised. Earthscan, London: 29-66.

(1991) 'Social Class', in P. Stringer and G. Robinson (eds.) Social Attitudes in Northern Ireland: 1990-91. Blackstaff, Belfast.

(1995) 'Development or Dependency? State, Economy and Society in Northern Ireland', in P. Clancy et al (eds.) Irish Society: Sociological Perspectives. Institute of Public Administration, Dublin.

O'Dowd, L., B. Rolston and M. Tomlinson (1980) Northern Ireland: Between Civil Rights and Civil War. CSE Books, Belfast.

O'Leary, B. (1999) 'The Nature of the British-Irish Agreement', in New Left Review 233: 66-96.

Ruane, J. (1996) 'The Core of Reason in Irish Revisions', in Anthropology Today $12(6): 1-2$.

Ruane, J. and J. Todd (1992) 'The Social Origins of Nationalism in a Contested Region: The Case of Northern Ireland', in J. Coakley (ed.) The Social Origins of Nationalist Movements: The Contemporary West European Experience. Sage, London: 187-211.

(1996) The Dynamics of Conflict in Northern Ireland: Power, Conflict and Emancipation. Cambridge University Press, Cambridge.

Ryan, M. (1994) War and Peace in Ireland: Britain and the IRA in the New World Order. Pluto, London.

Sennett, R., and J. Cobb (1972) The Hidden Injuries of Class. Faber \& Faber, London.

Shara, L. (1994) 'Thugs and Hooligans?', in Fortnight 325.

Sharrock, D. (1995) 'Wealth of Evidence Points to a Quiet Revolution in the Suburbs', in The Guardian, 25 May: 6. 
Sheehan, M. and M. Tomlinson (1995) 'Unemployment: A Long-Term Problem', in Democratic Dialogue (eds.) Social Exclusion, Social Inclusion. Report No.2, Belfast: 56-61.

Shirlow, P. and M. McGovern (1997) 'Counter-Insurgency, Deindustrialisation and the Political Economy of Ulster Loyalism', in P. Shirlow and M. McGovern (eds.) Who Are 'the People'? Unionism, Protestantism and Loyalism in Northern Ireland. Pluto, London: 176-98.

(1998) 'Language, Discourse and Dialogue: Sinn Féin and the Irish Peace Process', in Political Geography 17 (2): 171-86.

Smyth, J. (1991) 'Weasels in a Hole: Ideologies of the Northern Ireland Conflict' in Y. Alexander and A. O'Day (eds.) The Irish Terrorism Experience. Dartmouth, Aldershot.

Steedman, C. (1986) Landscape For a Good Woman: A Story of Two Lives. Virago, London.

Todd, J. (1990) Northern Irish Nationalist Political Culture', in Irish Political Studies 5: 31-44.

Wilson, T. (1989) Ulster: Conflict and Consent. Blackwell, London.

Many women write for us-Many women read us-You could be one of them

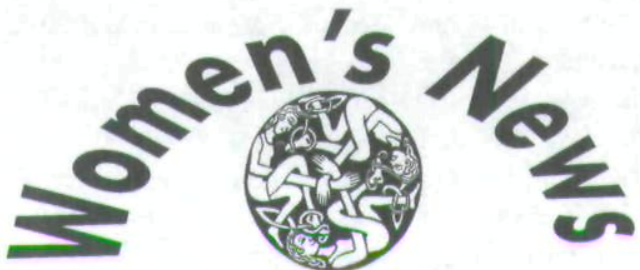

Read about the women who make the news and change the world, in politics, the arts and the world of entertainment...

Out every month, read throughout Ireland, Britain and further afield, it's a breath of fresh air for feminists, lesbians, 'straight' women, mothers, young women...

\section{Ireland's Feminist Monthly}

To subscribe, fill in the form and send, with a cheque to: women's news, 30 Donegall St., Belfast BT1 2 G0

$\begin{array}{lccrl}\text { Sub. rates (11 issues) } & \text { N.Ireland \& Britain } & \text { S. Ireland } & \text { Europe } & \text { Overseas } \\ \text { Unwaged } & £ 12.00 & \text { IR } £ 14.00 & £ 16.00 & \\ \text { Ordinary } & £ 18.00 & \text { IR } £ 20.00 & £ 24.00 & \\ \text { Groups/Support } & £ 20.00 & \text { IR } £ 22.00 & £ 24.00 & £ 28.00 \\ \text { Institutions } & £ 25.00 & \text { IR } £ 30.00 & £ 35.00 & £ 40.00\end{array}$

Name

Address . 
Copyright of Capital \& Class is the property of Conference Socialist Economist and its content may not be copied or emailed to multiple sites or posted to a listserv without the copyright holder's express written permission. However, users may print, download, or email articles for individual use. 